DOI 10.18551/rjoas.2019-03.19

\title{
EFFECT OF BRAND IMAGE AND SERVICE QUALITY ON CUSTOMER SATISFACTION AND LOYALTY AT BANK JATIM SYARIAH SURABAYA
}

\author{
Putro R. Nur Cahyo Adi ${ }^{\star}$, Rachmat Basuki \\ STIE Perbanas Surabaya, Indonesia \\ *E-mail: nurcahyoadiputro@gmail.com \\ ORCID 0000-0001-9948-2713
}

\begin{abstract}
The research objective is to examine the effect of brand image on customer satisfaction, examine the effect of service quality on customer satisfaction, and examine the effect of customer satisfaction on customer loyalty. The research hypotheses state that brand image has an effect on customer satisfaction, service quality has an effect on customer satisfaction, and customer satisfaction has an effect on customer loyalty. This research uses survey data from customers of Bank Jatim Syariah Surabaya. The data were collected using a questionnaire from respondents who were customers of Bank Jatim Syariah Surabaya, had at least one account at Bank Jatim Syariah Surabaya, and were at least 17 years old. The hypothesis testing techniques are carried out using SEM analysis with the AMOS program. The research findings indicated that brand image has a positive and not significant effect on customer satisfaction, service quality has a positive and significant effect on customer satisfaction, customer satisfaction has a positive and significant effect on customer loyalty at Bank Jatim Syariah Surabaya. This research showed that there is a positive and not significant correlation between brand image and customer satisfaction because the public knows Conventional Bank Jatim more; so that, Bank Jatim Syariah Surabaya is not yet widely known to the public. In addition, Civil Servants in Surabaya have long been permanent customers of Conventional Bank Jatim. Based on the research findings, the more satisfied customers, the more loyal customers will be at Bank Jatim Syariah.
\end{abstract}

\section{KEY WORDS}

Brand image, service quality, satisfaction, loyalty.

Indonesia is a country with a majority of Muslim population. It is common for sharia banking in this country to grow and develop. Its growth and development are enlivened by various sharia banks that compete in national competitions.

Sharia Business Unit, hereinafter referred to as UUS, is a work unit of the head office of a Conventional Commercial Bank that functions as the parent office of an office or unit that conducts business activities based on sharia principles, or work units in branch offices of a Bank domiciled abroad carry out conventional business activities and function as the parent office of the sharia supporting branch office and/or sharia unit (Law of the Republic of Indonesia number 21 of 2008 concerning Sharia Banking).

Based on the Best Syariah Award 2016 held by Investor Magazine, awards are given to the six best sharia banks which include:

Table 1 - Rank of Best Syariah Award

\begin{tabular}{|l|l|l|}
\hline No. & \multicolumn{1}{|c|}{ Bank } & \multicolumn{1}{c|}{ Assets } \\
\hline 1 & BNI Syariah & above IDR 10 trillion \\
\hline 2 & Bank Panin Syariah & below IDR 10 trillion \\
\hline 3 & Maybank Indonesia UUS & above IDR 5 trillion \\
\hline 4 & BPD Aceh UUS & IDR 1 trillion - IDR 5 trillion \\
\hline 5 & BPD DIY UUS & below IDR 1 trillion \\
\hline 6 & BPD Jambi UUS & below IDR 1 trillion \\
\hline
\end{tabular}

Source: Investor Magazine (2016). 
There are three Regional Development Banks (BPD) UUS which have the best title for sharia bank. East Java, along with its Bank Jatim Syariah UUS, has not been able to reach the sixth best rank on a national scale. This becomes an interesting problem to be researched, discussed and debated among practitioners and academics. It is about why UUS, which is located in one of the provinces on the Java Island that has a dense economic transaction, cannot win the title of the six best sharia banks on a national scale.

Indeed, East Java is one of the provinces with economic traffic that is no less crowded than Jakarta, West Java \& Banten, Central Java and the Special Region of Yogyakarta. East Java has a bank that is an icon and characteristic of East Java, i.e. PT. Bank Pembangunan Daerah Jawa Timur, Tbk, commonly referred to as Bank Jatim. Currently, Bank Jatim has a Sharia Business Unit (UUS) or called Bank Jatim Syariah Surabaya which was established based on Bank Indonesia Letter Number 9/75/DS/Sb dated April 4, 2007 concerning: Approval of the Principles of Establishment of Sharia Business Units (UUS), Office Opening Sharia Branch and Sharia Supervisory Board Members as well as Bank Indonesia Letter Number 9/148/DPIP/Prz/Sb dated July 24, 2007 concerning: Permission for Opening of Sharia Branch Offices. (http://www.bankjatim.co.id/id/syariah/profil).

Brand image on sharia banks is the perception that appears in the minds of the public towards sharia banks; does the sharia bank have a positive image or vice versa. According to Kotler and Armstrong (2008), a brand is a name, term, sign, symbol or design, or a combination of all that shows the identity of a product or service from a seller or group of sellers and distinguishes the product from competing products.

So that the formation of a brand image in a Sharia Bank becomes important in order to lead positive opinions among the people of their awareness to save and do all financial transactions in a Sharia Bank; in this case, Bank Jatim Syariah Surabaya. The more important is the creation of customer satisfaction in Bank Jatim Syariah Surabaya because customer satisfaction is the estuary of the sustainability of the sharia banking business. In a research conducted by Kurniawati (2014), brand image has a significant effect on customer satisfaction. That is also supported by Lahap et al (2015) research which concluded that there is a positive correlation between brand image and customer satisfaction. However, there is one research conducted by Sondakh (2014) that found a negative correlation between brand image and customer satisfaction (study on BNI Taplus Branch customers). Based on the above two different research findings, it becomes an interesting object to study about how brand image actually corelates to customer satisfaction.

Sharia banking service competition to customers is one of the attractions for customers who cannot be ignored. This is a factor that creates customer satisfaction in each sharia bank. However, customer satisfaction must also be accompanied by customer loyalty. Customer satisfaction is related to what is expressed by customers about their perceptions and expectations of the services they obtain. Meanwhile, loyalty is related to what customers do after interacting in the service process. This concept implies that customer satisfaction is not enough because complacency or dissatisfaction is only one form of emotion. Besides, customer loyalty is equally relevant to be analyzed. Based on a research conducted by Izogo and Ogba (2015), service quality is positively related to customer satisfaction and loyalty. There are also other researches that support it; i.e. a research conducted by Sondakh (2014) which concluded that service quality has a significant effect on customer satisfaction. Moreover, customer satisfaction has a significant effect on customer loyalty. Parasuraman in Kheng et al (2010) stated that service means the degree of difference arising from the service process and the interaction between service providers and customers.

The brand image and service quality of sharia bank of is very important for the creation of customer satisfaction and loyalty. This is an interesting thing for Bank Jatim Syariah Surabaya which is still very early in starting its business in the national domain. The customers are mostly engaged in the private sector and various levels of society in which the number of customers is not yet relatively large compared to Bank Jatim (conventional).

The spin off issue has been stated in the banking rules by the FSA. Bank Jatim Syariah Surabaya, which was inaugurated in 2007, has the opportunity of the Financial Services Authority to grow and develop until it is feasible to spin off. What is meant by spin off is 
separation as stipulated in the provisions governing sharia business units (Financial Services Authority Regulation Number 5/pojk.03/2016 concerning Bank Business Plans). With a maximum period of 2023, all Banks with Sharia Business Unit status (UUS) become Sharia Commercial Banks (BUS) (Bank Indonesia Regulation Number 15/14/PBI/2013 concerning Amendments to Bank Indonesia regulations number 11/10/PBI/2009 concerning Sharia Business Unit).

By the enactment of these regulations, Bank Jatim Syariah Surabaya is encouraged to do the best for its growth and readiness to become a BUS. Meanwhile, customer loyalty is important as a capital of readiness. Customer loyalty will be difficult to form if it is not accompanied by excellent service. In the preparation for spin off, how is the readiness of Bank Jatim Syariah Surabaya for its services to its customers? In addition, what is the brand image of Bank Jatim Syariah Surabaya in the minds of the public; considering that Bank Jatim Syariah has not been able to achieve the title of the best UUS sharia bank on a national scale.

Based on empirical studies and the results of an explanation of Bank Jatim Syariah Surabaya, this bank is one of the Islamic banks in East Java which contributed performance results in the ranking of Indonesia's sharia banking management even though it was relatively early in its development and breakthroughs for its progress. The preparation in welcoming spin off makes a condition for Bank Jatim Syariah to be able to develop and progress in accordance with the expectations of all stakeholders.

Does the brand image of Bank Jatim Syariah Surabaya create satisfaction in the community when they become customers of Bank Jatim Syariah Surabaya? Besides, how is the service quality of Bank Jatim Syariah Surabaya which is an appropriate strategy to make loyal and satisfied customers? A good brand image supported by reliable service quality to realize customer satisfaction and loyalty is the key to the success and sustainability of the Islamic banking business and determine the ranking of sharia banking management on a national scale.

Through the description of the above background, the author is interested in conducting a study with the title: "Effect of Brand Image and Service Quality on Customer Satisfaction and Loyalty at Bank Jatim Syariah Surabaya".

\section{LITERATURE REVIEW}

Brand image can be defined as a perception of an expectation that appears in the minds of customers when remembering a brand of a particular product. Here are some definitions of brand image:

According to the American Marketing Association in Kotler and Keller (2009), brand is name, term, sign, symbol, or design, or their combination, which is intended to identify goods or services from one seller or group of sellers and differentiate from competing goods or services.

According to Kotler and Armstrong (2008), a brand is a name, term, sign, symbol or design, or a combination of all these things that shows the identity of a product or service from one seller or group of sellers and distinguishes the product from competing products.

According to Lahap et al (2015), brand image is basically what goes into the minds of customers when the brand is placed in front of the customer. In other words, it means that when customers value brand names, they spontaneously think of the features of a brand.

Brand image is a perception of a brand that is a reflection of customer memory of its association with that brand (Ferrina Dewi, 2008).

Based on the above definition, it is concluded that brand image is a picture or impression that is generated by a brand in the customer's mind. Exposure of brand image in the minds and hearts of customers must be carried out continuously so that the brand image that is created remains strong and can be received positively. When a brand has a strong and positive image in the minds and hearts of customers, the brand will always be remembered. Then, the possibility of customers to buy the brand will be very high.

According to Lahap et al (2015), brand image indicators consist of: 
This bank provides convenience in transactions. This bank has a very clean image. This bank is luxurious. This bank is a place that is suitable for high class (luxury). I become special by visiting this bank. This bank staff is very kind. This bank has a long history. This bank has a different image than the others.

There are many opinions regarding the definition of quality because quality has a relative size of an item or service that is assessed by the attributes, design, and suitability of the buyers. The definition of service quality may be different. However, specifically it covers matters in determining whether the service is in accordance with customer expectations (Edgar and Galia, 2009). Customers assess service quality based on their perceptions of technical results which is the process by which the results are delivered.

Parasure in Kheng et al (2010) stated that service means the degree of difference arising from the service process and the interaction between service providers and customers.

Service quality has been conceptualized as the difference between customer expectations regarding the services they will receive and the perception of the services they have (Akbar and Parves, 2009). Service quality is a multidimensional concept (Bloemer et al, 1998).

SERVQUAL (Service Quality) has proven to be a model that has been widely used in various organizations and industries to measure service quality including the banking industry (Siddiqi, 2011). Although management has implemented the five dimensions of service quality as a reference for the application of the marketing concept, sometimes there are gaps or distances between the service quality perceived and accepted by customers with what they expect. Quality gaps are important because it is the overall assessment of the customer to what is expected compared to what is received (Lovelock and Wright, 2007).

According to Parasuraman (1988) in Kashif et al (2015) it includes:

- Tangible includes physical facilities, equipment, personnel and means of communication. The indicators can be seen from: tools and equipment used by modern sharia banks, attractive facilities offered by sharia banks, communication materials of sharia bank that are easy-to-understand, well-equipped sharia bank buildings;

- Reliability is the ability to produce promised service performance accurately and appropriately. Services must be on time and in the same specifications to minimize the possibility of errors. The indicators can be seen from: sharia bank employees that fulfill their promises, service specifications of sharia banks, sharia bank that provides services without error, the promised services of the sharia banks are available at all times;

- Responsiveness is the willingness to help customers and provide fast service. The indicators can be seen from: fast service to customers, ability to calm customers who make complain, providing help immediately to customers who experience a difficulty in transactions;

- Assurance includes knowledge and respect for employees. In this case their ability means a guarantee of the certainty to the services. The indicators can be seen from: sharia bank employees who are competent to be professional, sharia bank offers financially safe investments, sharia bank employees are polite, sharia bank employees have the appropriate knowledge;

- Empathy is inspiration and personal attention to customers. The indicators can be seen from: the attitude of sharia bank employees in providing services, the sensitivity of sharia bank employees in knowing customer interests, the sensitivity of sharia bank employees in knowing customer needs.

Kotler and Keller (2009) defined customer satisfaction as the level of one's feelings as a result of a comparison between reality and hope in a product and service. Parasuraman et al (1988) defined service quality as a customer assessment of the superiority or privilege of a service product as a whole. Akbar and Parves (2009) stated that satisfaction is a customer's evaluation of a product or service; whether or not the product or service has met their needs and expectations. 
Parasuraman and Berry (1988) defined service quality as a form of attitude that is related but not the same as satisfaction; as a result of a comparison between expectations and performance. Customer satisfaction plays an important role because it has a big difference in loyalty between customers who are simply satisfied and who are truly satisfied (Lovelock and Wright, 2007).

Based on the definition above, it is concluded that customer satisfaction is a positive feeling accompanied by attitudes of customers after they experience a situation or condition when they use the product or service.

Lahap et al (2015) elaborated customer satisfaction indicators as follows: hotel employees are friendly to customers, how well staff or managers know customers, how well banks listen to customer needs, convenient services, timeliness of bank staff in serving customers, bank administration fees, cheap banking product prices, affordable bank locations, easy bank access from airports and highways, good interior design/bank decoration, good facilities in the bank lobby, facilities offered by banks, excellent quality of bank services.

According to Pitchayadejanant and Nakpathom (2016), customer loyalty is defined as a very strong commitment to buy back products or services the customers like consistently in the future.

Rimiyati and Widodo (2014) stated that loyalty can be defined based on buying behavior. Loyal customers are people who: make repeated purchases regularly, buy interline products and services, refer the product to others, show ignorance to attraction from competitors.

Based on the various literature, the definition of loyalty is a level where customers make a repeated purchase behavior from a supplier of goods or services, have a positive attitude towards the company, and make the main consideration to use the company's products when they need particular goods or services.

According to Pitchayadejanant \& Nakpathom (2016), loyalty indicators include: I am happy to recommend this bank to others, I am proud to be a customer of this bank, this bank is my first choice, I will choose this bank continuously, this bank is very interesting, I want using this bank, this bank is good.

The findings of the research conducted by Kurniawati et al (2014) found that brand image has a significant effect on customer satisfaction. It was also supported by the findings of Lahap et al (2015) which stated that there is a positive correlation between brand image and customer satisfaction. The two studies illustrate that brand image has a positive correlation with customer satisfaction. However, a research conducted by Sondakh (2014) found a negative correlation between brand image and customer satisfaction (study on Manado Taplus BNI Branch customers) because the BNI brand image has been embedded in the minds of the community. Thus, BNl's brand image is not a problem for the community. That research is the basis of the researchers to examine the correlation between brand image and customer satisfaction at Bank Jatim Syariah Surabaya.

The results of the Al-Azzam study (2015) found that the scale of service quality (SERQUAL) has a significant and positive effect on customer satisfaction. It was also supported by findings from a study conducted by Ashdaq et al (2015) which stated that five service quality variables (SERQUAL) consisting of reliability, responsiveness, assurance, empathy, tangibles have a significant and positive effect on customer satisfaction. By the existence of a positive correlation from previous research, the researchers are interested in examining the correlation of service quality and customer satisfaction at Bank Jatim Syariah Surabaya.

The findings of the research conducted by Sondakh (2014) found that customer satisfaction had a significant effect on customer loyalty. By looking at the findings of previous studies that produced a positive and significant correlation on the two variables, the two variables were interesting to be examined which is related to the research on the correlation between customer satisfaction and customer loyalty at Bank Jatim Syariah Surabaya. 


\section{METHODS OF RESEARCH}

Research Population and Samples. The research population is the customers of Bank Jatim Syariah Surabaya Branch. Samples are part of the overall population carefully chosen so that it can represent the population (Sugiyono, 2012). Therefore, the research samples are part of the customers of Bank Jatim Syariah Surabaya with certain criteria.

The sampling technique in this research applies one method of purposive sampling; i.e. judgment sampling. According to Sugiyono (2012), the notion of purposive sampling is a technique of determining samples based on certain criteria or considerations. The criteria for determining the sample used in this research are as follows: becoming a customer of Bank Jatim Syariah Surabaya, having at least one account at Bank Jatim Syariah Surabaya, aged at least 17 years according to the minimum age for issuance of Citizen Identity Card or other Identity Card.

The sampling location is at Bank Jatim Syariah Surabaya. The questionnaire was distributed to customers who came to the Bank while waiting for the queue number to be called by Bank officers and also distributed to customers who had finished transacting at Bank Jatim Syariah Surabaya. The number of samples required from this research were 250 respondents. Determination of the sample number of 250 respondents is based on the opinion as follows: the sample size will also consider the method of data analysis. This research uses the data analysis technique of Structural Equation Modeling (SEM). The number of samples is at least 5 times the parameters that will be estimated or at least 100 (Hair et al, 2010). The indicators/ parameters used in this study are 46 items. To meet the minimum number of samples, $46 \times 5=230$ respondents. So, the researchers took samples for this research as many as 250 respondents.

Data Collection Technique. The method of data collection in this research is the questionnaire method; i.e. by giving written questions to respondents that are needed to be answered (Sugiyono, 2012). The questionnaire method is a list of written questions that have been formulated previously which will be answered by respondents in the form of a questionnaire. The questionnaire is given directly to the respondent who will fill it. In this research, the data is measured from respondents' perceptions of the questions in the questionnaire. Each respondent was required to express his/her opinion about the questions. These questions use five Likert scales ranging from one (strongly disagree) to five (strongly agree). The aim is that the researchers get more accurate data and the data show the real conditions of customers of Bank Jatim Syariah Surabaya.

\section{RESULTS AND DISCUSSION}

The data analysis used in this research is descriptive analysis which includes data on two hundred and fifty (250) respondents of Bank Jatim Syariah Surabaya customers on question indicators. Meanwhile, the statistical analysis in this research used Structural Equation Modeling (SEM).

Regarding the brand image of sharia bank in the minds of customers of Bank Jatim Syariah Surabaya, it appears that the overall average of the brand image variable is 3.66, which means that respondents tend to agree with the statement that the bank has a good brand image. The overall average of service quality variable is 3.87 which means that respondents tend to agree with the statement that Bank Jatim Syariah Surabaya has good service quality. The overall analysis shows that the average of service quality variable is 3.94. Based on the predetermined class intervals, respondents tend to agree with the statement that customers have high satisfaction with the services of Bank Jatim Syariah Surabaya. The analysis results show that the overall average of service quality variable is 3.98 which illustrates that respondents tend to agree with the statement that customers have high loyalty.

This technique of Confirmatory Factor Analysis is performed to test a theory or concept about a process or an understanding or a phenomenon (Ferdinand, 2000: 126). The following are the results of confirmatory factor analysis: 


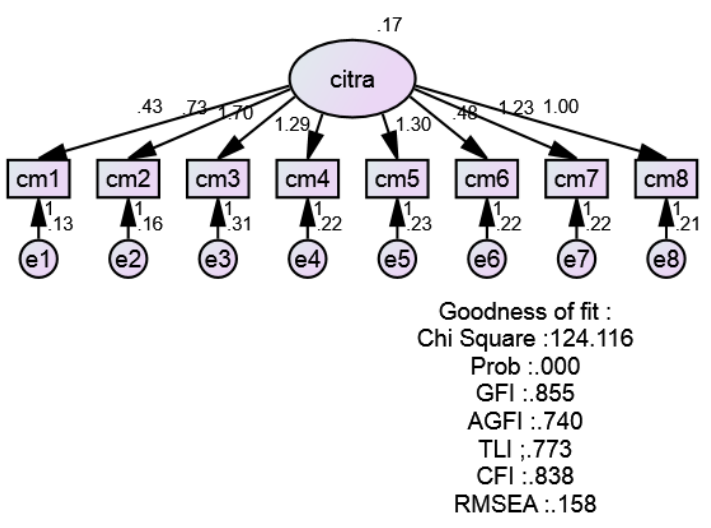

Figure 1 - Brand image model before being modified

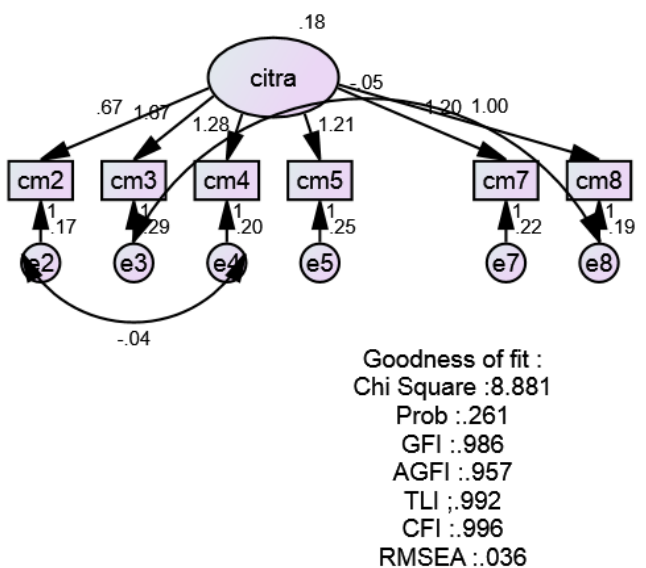

Figure 2 - Brand Image Model After Being Modified

Table 2 - Goodness of Fit on Modified Brand Image

\begin{tabular}{|c|c|c|c|}
\hline Goodness of Fit & Cut off Value & Estimate Results & Description \\
\hline Chi square & Kecil & 8.881 & Good \\
\hline Significance & $\geq 0.05$ & 0.261 & Good \\
\hline CMIN/df & $\leq 2.00$ & 1.269 & Good \\
\hline RMSEA & $\leq 0.08$ & 0.036 & Good \\
\hline GFI & $\geq 0.90$ & 0.986 & Good \\
\hline AGFI & $\geq 0.90$ & 0.957 & Good \\
\hline TLI & $\geq 0.95$ & 0.992 & Good \\
\hline CFI & $\geq 0.95$ & 0.996 & \\
\hline
\end{tabular}

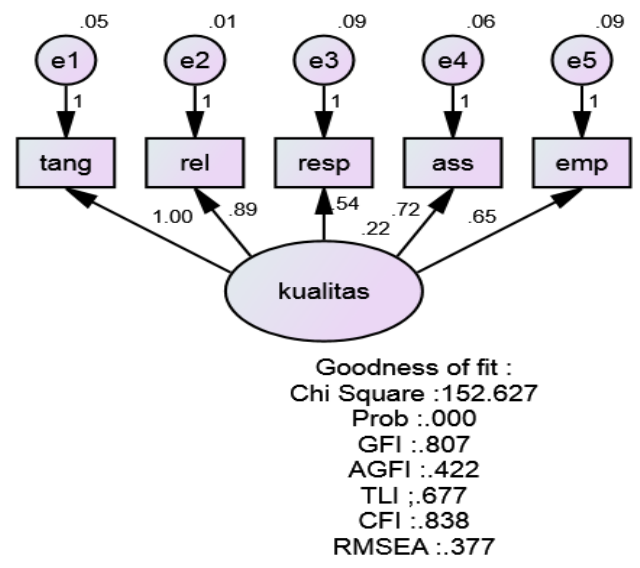

Figure 3 - Service quality model before being modified 


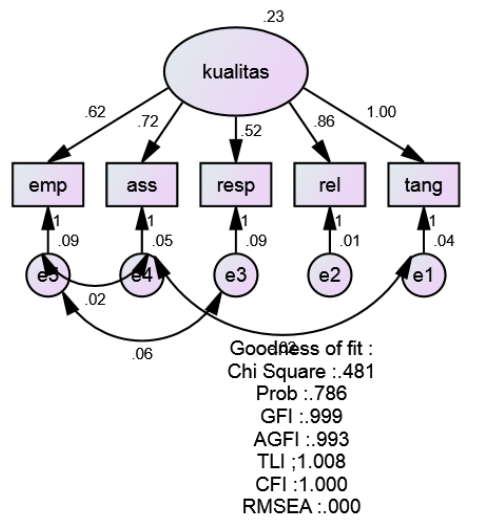

Figure 4 - Service quality model after being modified

Table 3 - Goodness of Fit on Modified Service Quality

\begin{tabular}{|c|c|c|c|}
\hline Goodness of Fit & Cut off Value & Estimate Results & Description \\
\hline Chi square & Kecil & 0.481 & Good \\
\hline Significance & $\geq 0.05$ & 0.786 & Good \\
\hline CMIN/df & $\leq 2.00$ & 0.240 & Good \\
\hline RMSEA & $\leq 0.08$ & 0.000 & Good \\
\hline GFI & $\geq 0.90$ & 0.999 & Good \\
\hline AGFI & $\geq 0.90$ & 0.993 & Good \\
\hline TLI & $\geq 0.95$ & 1.008 & Good \\
\hline $\mathrm{CFI}$ & $\geq 0.95$ & 1.000 & Good \\
\hline
\end{tabular}

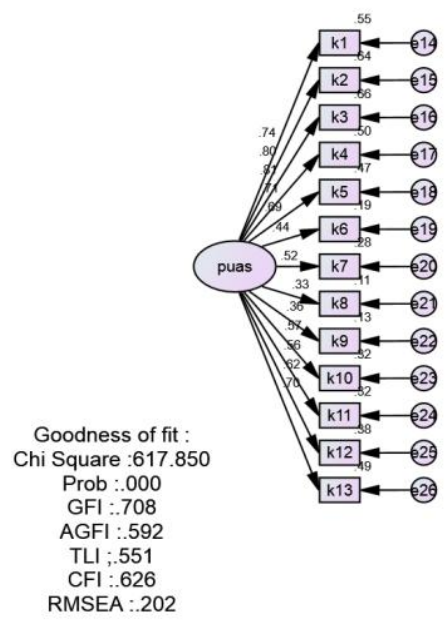

Figure 5 - Customer satisfaction model before being modified

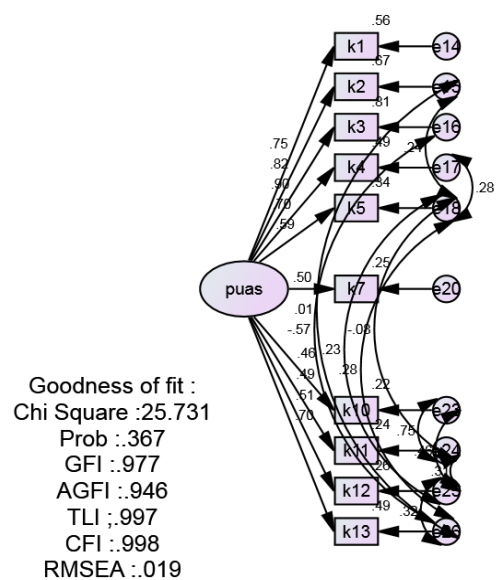

Figure 6 - Customer satisfaction model after being modified 
Table 4 - Goodness of Fit on Modified Customer Satisfaction

\begin{tabular}{|c|c|c|c|}
\hline Goodness of Fit & Cut off Value & Estimate Results & Description \\
\hline Chi square & Kecil & 25.731 & Good \\
\hline Significance & $\geq 0.05$ & 0.367 & Good \\
\hline CMIN/df & $\leq 2.00$ & 1.072 & Good \\
\hline RMSEA & $\leq 0.08$ & 0.019 & Good \\
\hline GFI & $\geq 0.90$ & 0.977 & Good \\
\hline AGFI & $\geq 0.90$ & 0.946 & Good \\
\hline TLI & $\geq 0.95$ & 0.997 & Good \\
\hline CFI & $\geq 0.95$ & 0.998 & \\
\hline
\end{tabular}

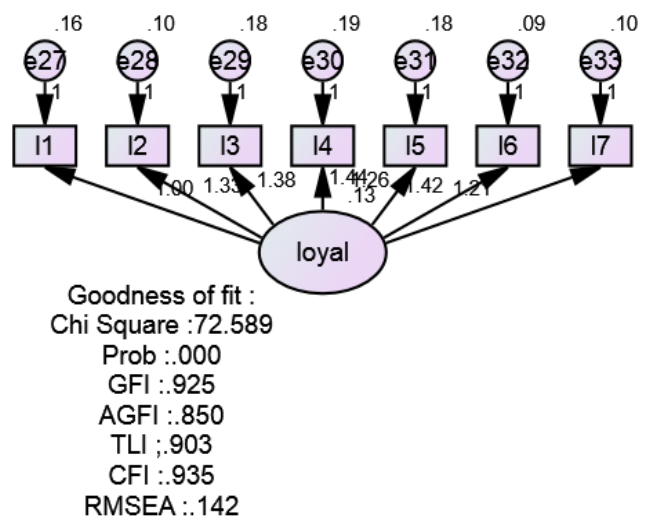

Figure 7 - Customer Loyalty Model before being modified

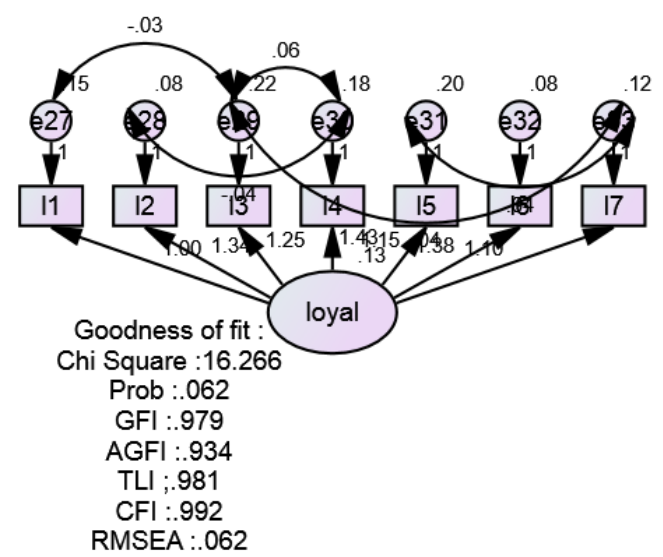

Figure 8 - Customer loyalty model after being modified

Table 5 - Goodness of Fit on Modified Customer Loyalty

\begin{tabular}{|c|c|c|c|}
\hline Goodness of Fit & Cut off Value & Estimate Results & Description \\
\hline Chi square & Kecil & 16.266 & Good \\
\hline Significance & $\geq 0.05$ & 0.062 & Good \\
\hline CMIN/df & $\leq 2.00$ & 1.807 & Good \\
\hline RMSEA & $\leq 0.08$ & 0.062 & Good \\
\hline GFI & $\geq 0.90$ & 0.979 & Good \\
\hline AGFI & $\geq 0.90$ & 0.934 & Good \\
\hline TLI & $\geq 0.95$ & 0.981 & Good \\
\hline CFI & $\geq 0.95$ & 0.992 & Good \\
\hline \multicolumn{2}{|l}{}
\end{tabular}

The test results show that the majority of variables are normally distributed because the c.r. values are less than 2.58. However, in term of multivariate, it does not meet the normality assumption with a c.r. value more than 2.58. This phenomenon does not become a serious problem as stated by Bentler and Chou (1987) that the estimate technique in the SEM model 
uses maximum likelihood estimation (MLE); even though the data distribution is not normal, it can still produce a good estimate, so that the data is feasible to be used in subsequent estimates. In addition, this research originates from primary data based on respondents' answers that are very diverse. Therefore, it is difficult to obtain data that follows a multivariate normal distribution.

Table 6 - Construct Reliability

\begin{tabular}{|c|c|c|c|c|c|c|}
\hline Variables & Construct & SFL Square & Error $[\varepsilon j]$ & $\mathrm{CR}$ & Cut off Value & Description \\
\hline \multirow{6}{*}{ Brand Image } & CM8 & 0.487 & 0.513 & \multirow{6}{*}{0.865} & \multirow{6}{*}{$>0.70$} & \multirow{6}{*}{ Reliable } \\
\hline & CM7 & 0.547 & 0.453 & & & \\
\hline & CM5 & 0.518 & 0.482 & & & \\
\hline & CM4 & 0.601 & 0.399 & & & \\
\hline & CM3 & 0.639 & 0.361 & & & \\
\hline & CM2 & 0.325 & 0.675 & & & \\
\hline \multirow{5}{*}{ Service Quality } & Tangible & 0.846 & 0.154 & \multirow{5}{*}{0.909} & \multirow{5}{*}{$>0.70$} & \multirow{5}{*}{ Reliable } \\
\hline & Reliability & 0.933 & 0.067 & & & \\
\hline & Responsiveness & 0.393 & 0.607 & & & \\
\hline & Assurance & 0.707 & 0.293 & & & \\
\hline & Empathy & 0.479 & 0.521 & & & \\
\hline \multirow{10}{*}{ Customer Satisfaction } & K1 & 0.558 & 0.442 & \multirow{10}{*}{0.878} & \multirow{10}{*}{$>0.70$} & \multirow{10}{*}{ Reliable } \\
\hline & K2 & 0.668 & 0.332 & & & \\
\hline & K3 & 0.810 & 0.190 & & & \\
\hline & K4 & 0.491 & 0.509 & & & \\
\hline & K5 & 0.343 & 0.657 & & & \\
\hline & K7 & 0.248 & 0.752 & & & \\
\hline & K10 & 0.215 & 0.785 & & & \\
\hline & K11 & 0.241 & 0.759 & & & \\
\hline & K12 & 0.255 & 0.745 & & & \\
\hline & K13 & 0.490 & 0.510 & & & \\
\hline \multirow{7}{*}{ Customer Loyalty } & L1 & 0.476 & 0.524 & \multirow{7}{*}{0.910} & \multirow{7}{*}{$>0.70$} & \multirow{7}{*}{ Reliable } \\
\hline & L2 & 0.759 & 0.241 & & & \\
\hline & L3 & 0.496 & 0.504 & & & \\
\hline & L4 & 0.610 & 0.390 & & & \\
\hline & L5 & 0.465 & 0.535 & & & \\
\hline & L6 & 0.755 & 0.245 & & & \\
\hline & $\mathrm{L} 7$ & 0.584 & 0.416 & & & \\
\hline
\end{tabular}

Table 7 - Normality test

\begin{tabular}{|c|c|c|c|}
\hline Variables & Cut off value & c.r. & Description \\
\hline Empathy & \pm 2.58 & 1.2285 & Normal \\
\hline Assurance & \pm 2.58 & .6805 & Normal \\
\hline Responsibility & \pm 2.58 & 2.8731 & Not Normal \\
\hline Reliability & \pm 2.58 & 3.6143 & Not Normal \\
\hline Tangible & \pm 2.58 & -.2177 & Normal \\
\hline Loyalty & \pm 2.58 & .8896 & Normal \\
\hline Satisfaction & \pm 2.58 & 1.0580 & Normal \\
\hline Brand Image & \pm 2.58 & -.4344 & Normal \\
\hline \multicolumn{2}{|c|}{ Multivariate } & 14.9539 & \\
\hline
\end{tabular}

Outlier evaluations show that there is a Z-score that is less than -3. Therefore, it is concluded that there are univariate outliers. The amount of the eliminated data, because the value is less than -3 , is 33 people. Therefore, the amount of data used for the next test is 217 people.

The results of multivariate outliers showed that the mahalanobis value was in the range of 3.608 to 108.089 . The maximum value of the mahalanobis indicates a multivariate outlier because the value is more than 81.40 . The data affected by outliers is 9 data. So, the $9^{\text {th }}$ data must be omitted before analyzing to the next stage with the current data amount of 209 data. 
The next test is to analyze Structural Equation Modeling (SEM) with a full model based on theory. The analysis of Structural Equation Modeling (SEM) was carried out using the AMOS 22.0 program with a composite model. It is because the chi-square value in the initial model is relatively high. The SEM results on the initial model proposed are as follows:

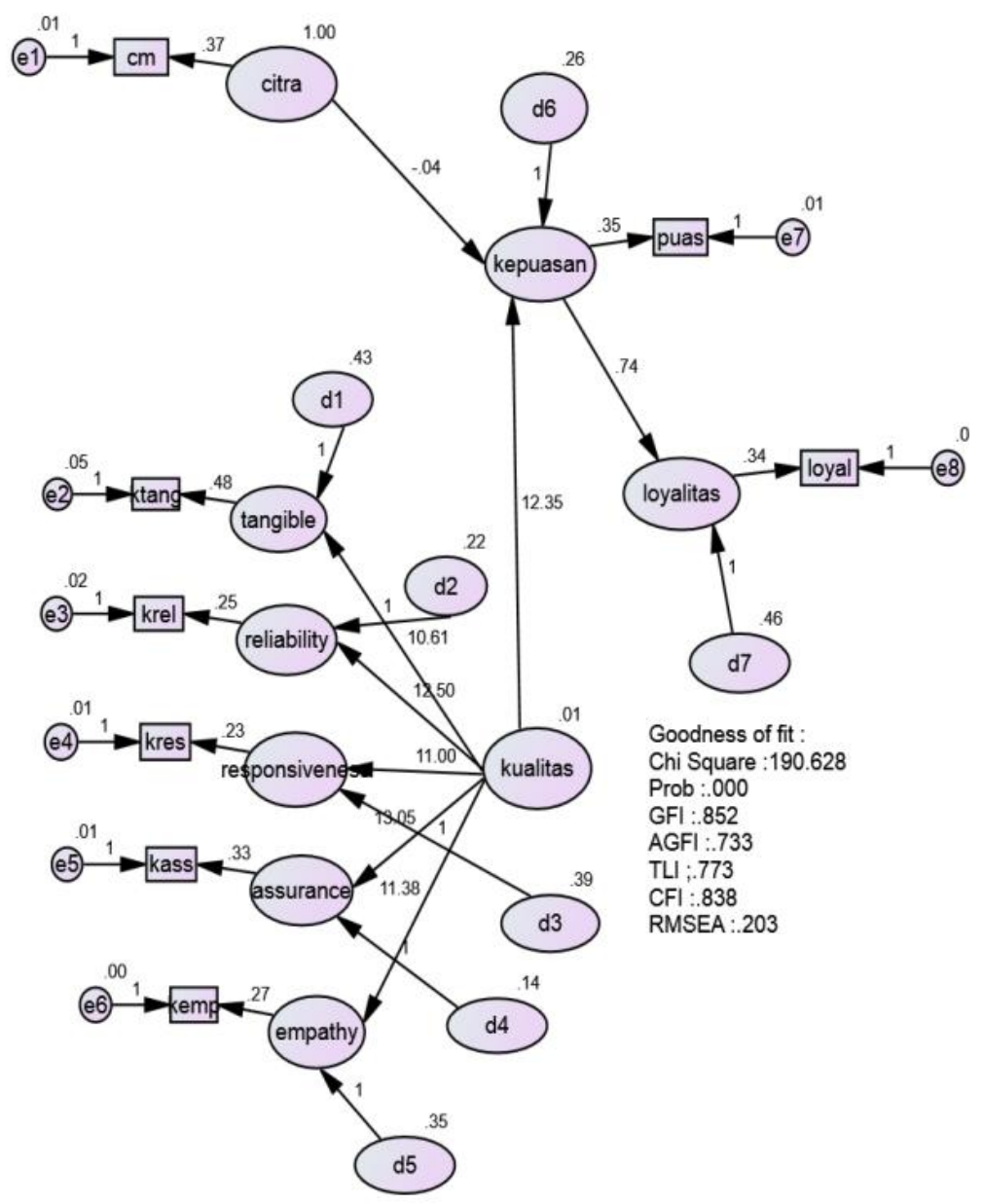

Figure 9 - Structural Equation Modeling (SEM) Full Model

Table 8 - Goodness of Fit of Structural Equation Model

\begin{tabular}{|c|c|c|c|}
\hline Goodness of Fit & Estimate Results & Cut off Value & Description \\
\hline Chi-square & 190,628 & It is expected to be small & Marginal \\
\hline Cmin/DF & 9.5314 & $\leq 2.00$ & Marginal \\
\hline Probability & 0.000 & $\geq 0.05$ & Marginal \\
\hline GFI & 0.852 & $\geq 0.90$ & Marginal \\
\hline AGFI & 0.733 & $\geq 0.90$ & Marginal \\
\hline TLI & 0.773 & $\geq 0.95$ & Marginal \\
\hline CFI & 0.838 & $\geq 0.95$ & Marginal \\
\hline RMSEA & 0.203 & $\leq 0.08$ & \\
\hline
\end{tabular}

Analysis of structural equation modeling is intended to test models that have been developed based on theory simultaneously. Based on the results of the model feasibility test, the probability value is less than $5 \%$ which is equal to 0.000 . It shows that there is a mismatch of the model so that it requires a modification of the model, even though the majority of the criteria have met the predetermined cut-off value.

From the initial full model, it was found that the population covariance variant matrix was not the same as the model of estimate covariance variant matrix so that modification of the model was carried out by correlating the residuals as follows: 


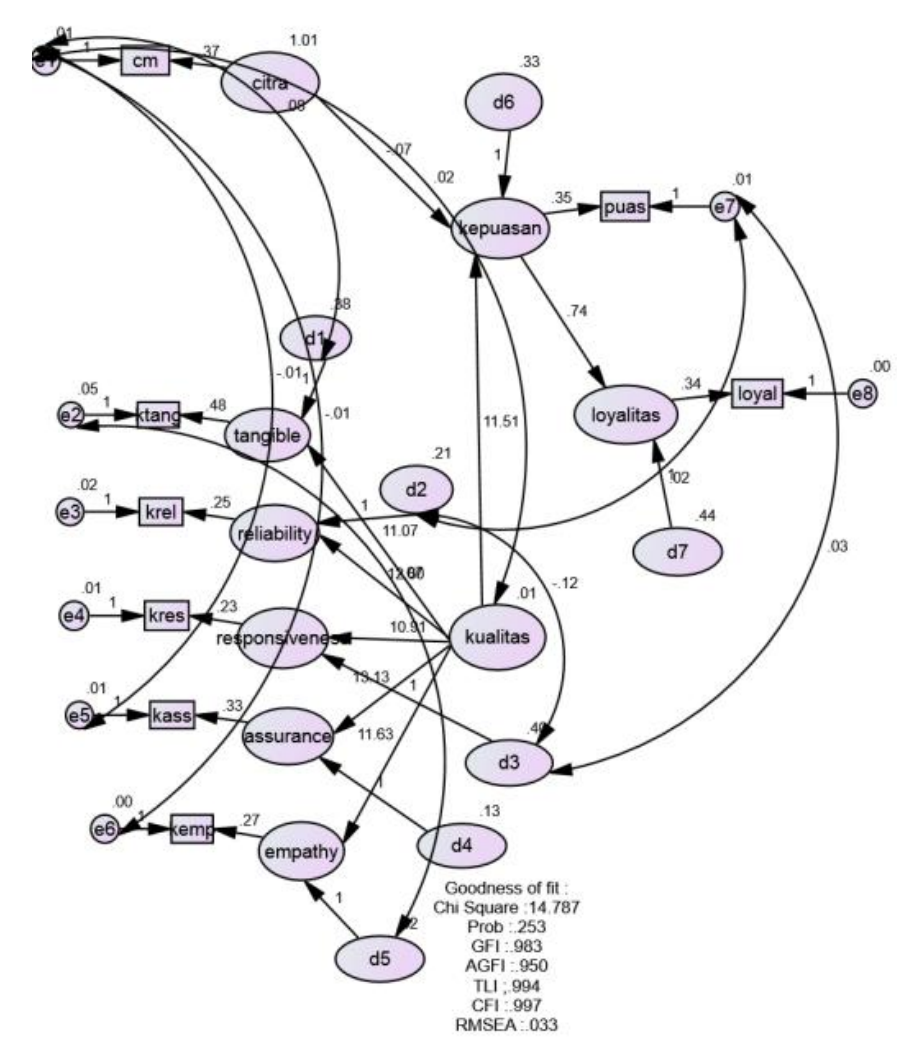

Figure 10 - Structural Equation Modeling (SEM) Full Model after being modified

Table 9 - Goodness of Fit of Modified Structural Equation Model

\begin{tabular}{|c|c|c|c|}
\hline Goodness of Fit & Estimate Results & Cut off Value & Description \\
\hline Chi-square & 14.787 & It is expected to be small & Good \\
\hline Cmin/DF & 1.232 & $\leq 2.00$ & Good \\
\hline Probability & 0.253 & $\geq 0.05$ & Good \\
\hline GFI & 0.983 & $\geq 0.90$ & Good \\
\hline AGFI & 0.950 & $\geq 0.90$ & Good \\
\hline TLI & 0.994 & $\geq 0.95$ & Good \\
\hline CFI & 0.997 & $\geq 0.95$ & Good \\
\hline RMSEA & 0.033 & $\leq 0.08$ & Good \\
\hline
\end{tabular}

The modification of the structural model results in a value decrease with a probability of 0.253 which is greater than $5 \%$. Thus, the population covariant variant matrix that is the same as the estimated variant of the covariant model has been obtained. In addition to this probability value, all criteria have met the specified cut-off value. After getting the appropriate model, the significance of the model is obtained by comparing the probability value of each causality correlation with $\alpha(5 \%)$. The loading and significance values are presented in the following table:

Table 10 - Regression Weight Structural Equation Model

\begin{tabular}{|c|c|c|c|c|c|}
\hline \multicolumn{3}{|c|}{ Variables } & Std Estimate & P-Value & Description \\
\hline Customer Satisfaction & $\epsilon$ & Brand Image & -0.0686 & 0.045 & Not Significant \\
\hline Customer Satisfaction & $\leftarrow$ & Service Quality & 0.8163 & 0.000 & Significant \\
\hline Customer Loyalty & $\leftarrow$ & Customer Satisfaction & 0.7440 & 0.000 & Significant \\
\hline
\end{tabular}

\section{CONCLUSION AND SUGGESTIONS}

Brand image has a positive and not significant effect on customer satisfaction at Bank Jatim Syariah Surabaya; thus, $\mathrm{H} 1$ is rejected. Service quality has a positive and significant effect on customer satisfaction at Bank Jatim Syariah Surabaya; thus, H2 is accepted. 
Customer satisfaction has a positive and significant effect on customer loyalty at Bank Jatim Syariah Surabaya; thus, $\mathrm{H} 3$ is accepted.

Based on the analysis results of the research that has been conducted, the following suggestions can be submitted:

1. STIE Perbanas Surabaya is expected to maintain the quality of its education which has produced graduates in management postgraduate program as a superior generation that benefits the people of East Java in particular and the Indonesian people in general;

2. For Bank Jatim Syariah recommended to maintain its service quality as a capital of success and as a provision and preparation in facing the spinoff of Conventional Bank Jatim. Bank Jatim Syariah Surabaya is advised to evaluate and record which equipment might not be able to keep up with the era so that they can be upgraded with more modern equipment. Bank Jatim Syariah Surabaya should be able to pay more attention to interior design/ decoration at the banking hall and all transaction locations with customers to look more luxurious.

\section{REFERENCES}

1. Akbar, M. M., \& Parvez, N. (2009). Impact of service quality, trust, and customer satisfaction on customers loyalty. ABAC Journal, 29(1).

2. Ashdaq, M., Maupa, H., Amar, M. Y., \& Nursyamsi, I. (2015). Analysis of Service Quality On Pilgrims Satisfaction And Image Of Hajj And Umrahs Travel Agents In South Sulawesi Province, Indonesia. International Journal of Research In Social Sciences, 5(6).

3. Bentler, P. M., \& Chou, Chih Ping. (1987). Practical issues in structural modeling. Sociological Methods and Research, 16, 78-117.

4. Bloemer, J., De Ruyter, K., \& Peeters, P. (1998). Investigating drivers of bank loyalty: the complex relationship between image, service quality and satisfaction. International Journal of bank marketing, 16(7), 276-286.

5. Edgar, M., \& Galia, F. (2009). Why and How Service Quality Perceptions Impact Cunsomer Responses. Journal of Managing Service Quality. 19(4): 474-485.

6. Ferrinadewi, E. (2008). Merek dan Psikologi Konsumen, Implikasi pada Strategi Pemasaran. Yogyakarta: Graha IImu.

7. Hair, J. F., Black, W. C., Babin, B., Anderson, R. E., \& Tatham, R. L. (2010). Multivariate Data Analysis (6th). New Jersey: Pearson Prentice Hall.

8. Izogo, E. E., \& Ogba, I. E. (2015). Service quality, customer satisfaction and loyalty in automobile repair services sector. International Journal of Quality \& Reliability Management, 32(3), 250-269.

9. Kashif, M., Wan Shukran, S. S., Rehman, M. A., \& Sarifuddin, S. (2015). Customer satisfaction and loyalty in Malaysian Islamic banks: a PAKSERV investigation. International Journal of Bank Marketing, 33(1), 23-40.

10. Kheng, L. L., Mahamad, O., \& Ramayah, T. (2010). The impact of service quality on customer loyalty: A study of banks in Penang, Malaysia. International journal of marketing studies, 2(2), 57.

11. Kotler, P., \& Amstrong, G. (2008). Prinsip-prinsip Pemasaran (Vol. Edisi 12). Jakarta: Erlangga.

12. Kotler, P., \& Keller, K.L. (2009). Manajemen Pemasan. Jilid 2. Jakarta: Erlangga.

13. Kurniawati, D., Suharyono, \& Kusumawati, A., (2014). Pengaruh Citra Merek dan Kualitas Produk Terhadap Kepuasan dan Loyalitas Pelanggan (Studi pada Pelanggan KFC Cabang Kawi Malang). Jurnal Administrasi Bisnis, 14(2).

14. Lahap, J., Ramli, N. S., Said, N. M., Radzi, S. M., \& Zain, R. A. (2016). A study of brand image towards customer's satisfaction in the Malaysian hotel industry. Procedia-Social and Behavioral Sciences, 224, 149-157.

15. Lovelock, C., \& Wright, L. K., 2007. Manajemen Pemasaran Jasa. Indonesia: PT. Indeks.

16. Parasuraman, A. (1988). Servqual : A Multiple-Item Scale for Measuring Consumer Perception of Service Quality. Journal of Retailing, Volume 64, 12-40. 
17. Parasuraman, A., Zeithaml, V. A., \& Berry, L. L. (1988). Servqual: A multiple-item scale for measuring consumer perc. Journal of retailing, 64(1), 12.

18. Pitchayadejanant, K., \& Nakpathom, P. (2016). The effect of demographic information as moderator toward relationship between service quality, customer satisfaction, and customer loyalty in Thai Low cost carriers' passengers. Journal of Marketing Management, 4(1), 172-182.

19. Rimiyati, H., \& Widodo, C. (2014). Pengaruh citra merek, kualitas produk, kepuasan konsumen terhadap loyalitas konsumen merek Samsung Galaxy Series (Studi pada mahasiswa Universitas Muhammadiyah Yogyakarta). Jurnal Manajemen Bisnis, 5(2), 223-234.

20. Siddiqi, K.O. (2011). Between Service Quality Attributes, Customer Satisfaction and Customer Loyalty in The Retail Banking Sector in Bangladesh. International Journal of Business and

21. Sondakh, C. (2015). Kualitas Layanan, Citra Merek Dan Pengaruhnya Terhadap Kepuasan Nasabah Dan Loyalitas Nasabah Tabungan (Studi Pada Nasabah Taplus BNI Cabang Manado). Jurnal Riset Bisnis dan Manajemen, 3(1).

22. Sugiyono., 2012. Metode Penelitian Kuantitatif Kualitatif dan R\&B. Bandung: Alfabeta.

23. Undang-Undang Republik Indonesia Nomor 21 Tahun 2008 Tentang Perbankan Syariah).

24. Zeithaml, L., \& Valerie, A. (1988, July). Consumer Perceptions of Price, Quality, and Value: A Means End Model and Synthesis of Evidence. Journal of Marketing, Vol 52, 222. 